\title{
Arsenic residues in broiler meat and excreta at arsenic prone areas of Bangladesh
}

\author{
Amalendu Ghosh', Md. Abdul Awal'2, Shankar Majumder3, Mahmudul Hasan Sikder3 and \\ Damanna Ramkishan Rao4 \\ ${ }^{1}$ Upazila Livestock Office, Netrokona Sadar, Netrokona, Bangladesh; ${ }^{2}$ Department of Pharmacology, Bangladesh \\ Agricultural University, Mymensingh, Bangladesh; ${ }^{3}$ Department of Agricultural Statistics, Bangladesh Agricultural \\ University, Mymensingh, Bangladesh; ${ }^{4}$ National Institute of Food and Agriculture-USDA, USA.
}

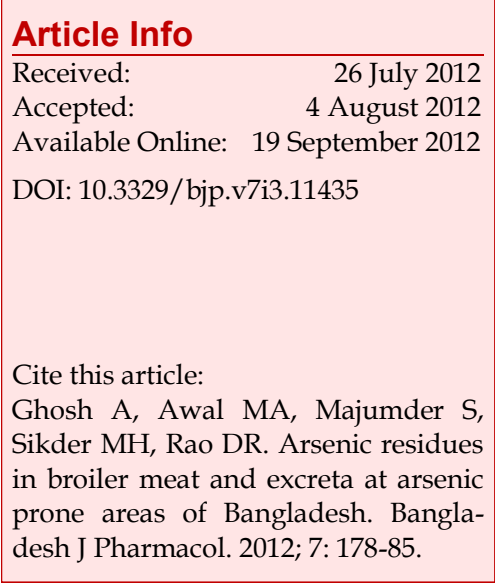

\begin{abstract}
The aims of this study were to detect arsenic concentrations in feed, drinking water, tissues and excreta of broiler chickens in Bangladesh; and to assess the effect of arsenic in feed and drinking water on the retention of arsenic in broiler tissues and excreta. Total arsenic concentration (inorganic plus organic) was determined by atomic absorption spectrophotometer. Mean ( \pm SE) levels of arsenic in drinking water, feed (dry weight) and excreta (dry weight) were $80.4 \pm 5.5 \mu \mathrm{g} / \mathrm{L}, 119.0 \pm 4.7$ and $1221.8 \pm 58.3 \mu \mathrm{g} / \mathrm{kg}$, respectively. In tissues (wet weight), highest arsenic concentration $(\mu \mathrm{g} / \mathrm{kg})$ was in skin $(218.8 \pm 11.7)$, followed by liver $(102.1 \pm 8.0)$, lung $(96.3 \pm 5.6)$, kidney $(88.2 \pm 7.5)$ and thigh muscle $(67.8 \pm 5.1)$. Arsenic in broiler meat was below the maximum tolerable limits for humans. Accumulations of arsenic in tissues and excreta were boosted with the relative increment of arsenic in drinking water and feed. High arsenic in excreta could be an environmental issue in Bangladesh.
\end{abstract}

\section{Introduction}

Peoples of Bangladesh facing singular challenges related to food quality and safety. Arsenic is one of the major culprits that contaminates food chain and makes significant contribution to induce arsenic-related diseases in Bangladesh (Khan et al., 2010). It was estimated that 59 out of 64 districts of Bangladesh are contaminated with arsenic (Chakraborti et al., 2010). Due to serious consequence, WHO leveled the arsenic disaster of Bangladesh as "the largest mass poisoning of a population in history" (Smith et al., 2000). Contamination of food chain by arsenic is a newly uncovered disaster on a massive scale (Zhao et al., 2010; Singh and Ghosh, 2011), although little research has focused on food as an additional source of arsenic exposure. Uses of some feed additives, like roxarsone, increase arsenic loads in chicken meat and consequently adds arsenic in the environment (Wallinga, 2006).

Poultry provides hard-cash income and creates employment opportunities for the rural and landless farmers in Bangladesh. Broiler chickens in Bangladesh are now providing an unprecedented range of relatively low cost meat products for consumers. Under Bangladesh conditions most of the poultry farms are maintaining with shallow well water, which contain relatively more arsenic than deep well water. Feeding broilers with arsenic-rich food and/or water contribute to the accumulation of arsenic loads in its meat and excreta (Islam et al., 2009). Nevertheless, cooking of arsenic intoxicated meat may create additional arsenic-rich toxic by-products for consumers (Hanaoka et al., 2001). Public health workers have expressed concern about the arsenic content of chicken meat for its role in human dietary exposures (Lasky et al., 2004). Moreover, arsenic 
has been identified as a roadblock to potential animal waste management solutions (Nachman et al., 2005). There is limited information about the level of arsenic in broiler meat and excreta produced by birds fed arsenic-rich feed and/or drinking water in Bangladesh (Islam et al., 2009). Effects of accumulation of arsenic after long-term intake of low doses to broiler chickens remain obscure. The objective of the study is to determine the concentration of arsenic in feed, drinking water, tissues and excreta of broiler chicken in arsenicprone areas of Bangladesh and to assess the effect arsenic in feed and drinking water on arsenic retention in broiler tissues and excreta.

\section{Materials and Methods}

\section{Selection of broiler birds}

A restricted observational (survey) study design was conducted in this work. Purposive sampling procedure was applied at the different stages except the ultimate sample selection of the broiler chickens. A total of 116 semi-commercial broiler farms (herd size from 200 to 500 heads) were selected purposively from five arsenicprone areas (Madaripur, Chandpur, Jessore, Satkhira and Faridpur) of Bangladesh on the basis of predefined criteria of broiler age ( $\geq 15$ days) and availability of records on the source of feed and drinking water. Broiler birds were maintained in small houses on floor with low to minimal biosecurity. Two broiler chickens (one male and one female) from each farm were chosen randomly.

\section{Sample collection}

Samples were collected between March-May in 2009 by interviewing the chicken owners with a prearranged questionnaire. Questionnaire was structured including general information (area, age, sex, body weight and feed type) of specific chicken. Information about water source and depths of tube wells were obtained on the basis of the questionnaire. Drinking water samples of chickens were collected in $50 \mathrm{~mL}$ acid washed polyethylene vial as previously described (Pandey et al., 2004). Briefly, water samples were collected from mid-stream after pumping the tube wells vigorously for at least $10 \mathrm{~min}$. Immediately after collection, water samples were filtered with capsule filter $(0.45 \mu \mathrm{m}$ pore), and collecting vials were flushed with filtered water for about one min. Vials were filled up to the top by filtered water. An aliquot of $100 \mu \mathrm{L}$ concentrated nitric acid (Merck, Germany) was added (prior to water collection) to acidify the sample to a $\mathrm{pH}<2.0$ and to prevent precipitation of iron and co-precipitation of arsenic (Clesceri et al., 1989). About 50 g poultry feed was collected from each farm. For collecting excreta, selected broiler chickens were kept separately at farm, one in cage until drooping, bedding with clean and dry acid washed polyethylene mat with ad libitum feed and drinking water. Drooping (10-15 g) was collected aseptically from each chicken. Chickens were euthanized at farm; and liver, kidney, lung, skin and thigh muscle (5-10 $\mathrm{g}$ of each) were harvested. Excreta and tissues were stored at $-20^{\circ} \mathrm{C}$.

\section{Analytical methods}

All reagents were of analytical grade. Millipore water was used throughout. Poultry feed and excreta were oven-dried at $60^{\circ} \mathrm{C}$, and ground with a stainless steel grinder (Karl Kolb, Scientific Technical Supplies, West Germany). It was passed through 100 mesh sieve (pore size $0.15 \mathrm{~mm}$ ) and stored in desiccators. Before digestion they were further oven- dried to get constant weight. After thawing to a workable level, aliquots of broiler tissue was cleaned, and washed in phosphate buffer saline (PBS) to remove clotted blood and debris. This was air dried in Petri dish keeping on ice, chopped into small chunks to create a composite. Poultry feed (dry weight) were digested at $120^{\circ} \mathrm{C}$ using concentrated nitric acid and 30\% hydrogen peroxide (Peters, 2003). Tissues (wet weight) and excreta (dry weight) were digested heating up to $150^{\circ} \mathrm{C}$ by sequentially adding triple acid mixture (nitric acid - 10 parts, perchloric acid - 3 parts and sulphuric acid - 1 part) and 30\% hydrogen peroxide (Cox, 1980). Digestion was carried out in a block digester (M-24 plazas/samples, JP Selecta, Spain).

Concentrations of total arsenic (inorganic plus organic) in drinking water and digested samples were determined using atomic absorption spectrophotometer coupled with hydride generator (PG Instruments Ltd., UK). Detection limit of the instrument for arsenic was 2 $\mu \mathrm{g} / \mathrm{L}$. Arsenic pentoxide (Merck, Germany; 1,000,000 $\mu \mathrm{g} / \mathrm{L})$ was used as standard. Quantification of arsenic was performed by spiking samples with working standard of $0,2.5,5,10,15$ and $20 \mu \mathrm{g} / \mathrm{L}$, prepared immediately before use by serial dilution of the stock in $10 \%$ hydrochloric acid. In every occasion the linear correlation factor was bigger than 0.99. The salient features instrument setting and carriers were light source: ordinary hollow-cathode lamp; carrier gas: Pure argon; carrier liquid: One percent hydrochloric acid; wavelength: $193.7 \mathrm{~nm}$.

\section{Quality control}

Accuracy and precision of analyses were evaluated using commercially available standard reference materials (SRM) from National Institute of Standards and Technology (NIST) with certified or recommended arsenic concentrations. Every fifteen samples one blank and one SRM were digested as sample. There was good conformity between obtained arsenic concentrations in the SRMs and the reference values, signifying good analytical performance. For water SRM 1643e (aqueous acidified water $60.5 \pm 0.7 \mu \mathrm{g} / \mathrm{L}$, recovery rate: 93 to $102 \%$ ), for poultry feed and excreta SRM 1568a (solid 
rice flour $290 \pm 30 \mu \mathrm{g} / \mathrm{kg}$, recovery rate: 91 to $99 \%$ ) and for broiler tissues SRM 1577b (bovine liver $47 \pm 5 \mu \mathrm{g} /$ $\mathrm{kg}$, recovery rate: 85 to $103 \%$ ) were used.

\section{Statistical analyses}

Information regarding broiler chickens were stratified according to area, age, sex, drinking water source and arsenic levels in drinking water and feed. F-test was used for testing the equality of several means. Least significant difference (lsd) test was performed for multiple comparisons among the means in a particular item (Steel and Torrie, 1980). Pearson's correlation coefficient was computed to determine the degree of linear relationship between the two variables under consideration. Multivariate multiple regression analysis, a logical extension of the multiple regression concept to allow for multiple responses was done to explore the effects of the explanatory variables on the dependent variables (Johnson and Wichern, 2002). Area (ref: Faridpur), age, sex, body weight, arsenic content in drinking water and feed were considered as explanatory variables, whereas arsenic retained in thigh muscle, liver, kidney, skin, lung and excreta were considered as dependent variables. For the multivariate analysis, body weight, arsenic contents in drinking water, feed, thigh muscle, liver, kidney, skin, lung and excreta were log-transformed to remove the bad impact of the extreme values. All the data were analyzed using the Statistical Package for Social Sciences (SPSS, Chicago, IL) software. Multivariate regression analyses were carried out using Stata10 software (StataCorp, 2007).

\section{Results}

A total of 232 broiler chickens were considered for arsenic detection. Table I presents classification of broiler chickens based on the geographic area, age, sex, sources of feed and drinking water, and arsenic exposure levels from drinking water and feed. A majority of the chickens $(69.8 \%)$ consumed shallow tube well water. Most of them consumed water (51.7\%) and feed (54.3\%) tainted by arsenic $>50 \mu \mathrm{g} / \mathrm{L}$ and within $100 \mu \mathrm{g} / \mathrm{kg}$, respectively.

The overall concentration of arsenic in well water was $80.4 \pm 5.5 \mu \mathrm{g} / \mathrm{L}$ (Table II). A significant $(\mathrm{p}<0.01)$ difference in the arsenic contents of well water up to $90 \mathrm{~m}$ and above $90 \mathrm{~m}$ were observed; but difference up to 45 $\mathrm{m}$ and within 46-90 $\mathrm{m}$ were insignificant $(\mathrm{p}>0.05)$. The overall arsenic concentration in broiler feed (dry weight) was $119.0 \pm 4.7 \mu \mathrm{g} / \mathrm{kg}$, which differed significantly $(\mathrm{p}<0.01)$ from area to area (Table III). The overall levels $(\mu \mathrm{g} / \mathrm{kg})$ of arsenic in thigh muscle, liver, kidney, lung and skin of broiler chickens were 67.8 \pm 5.1, $102.1 \pm$

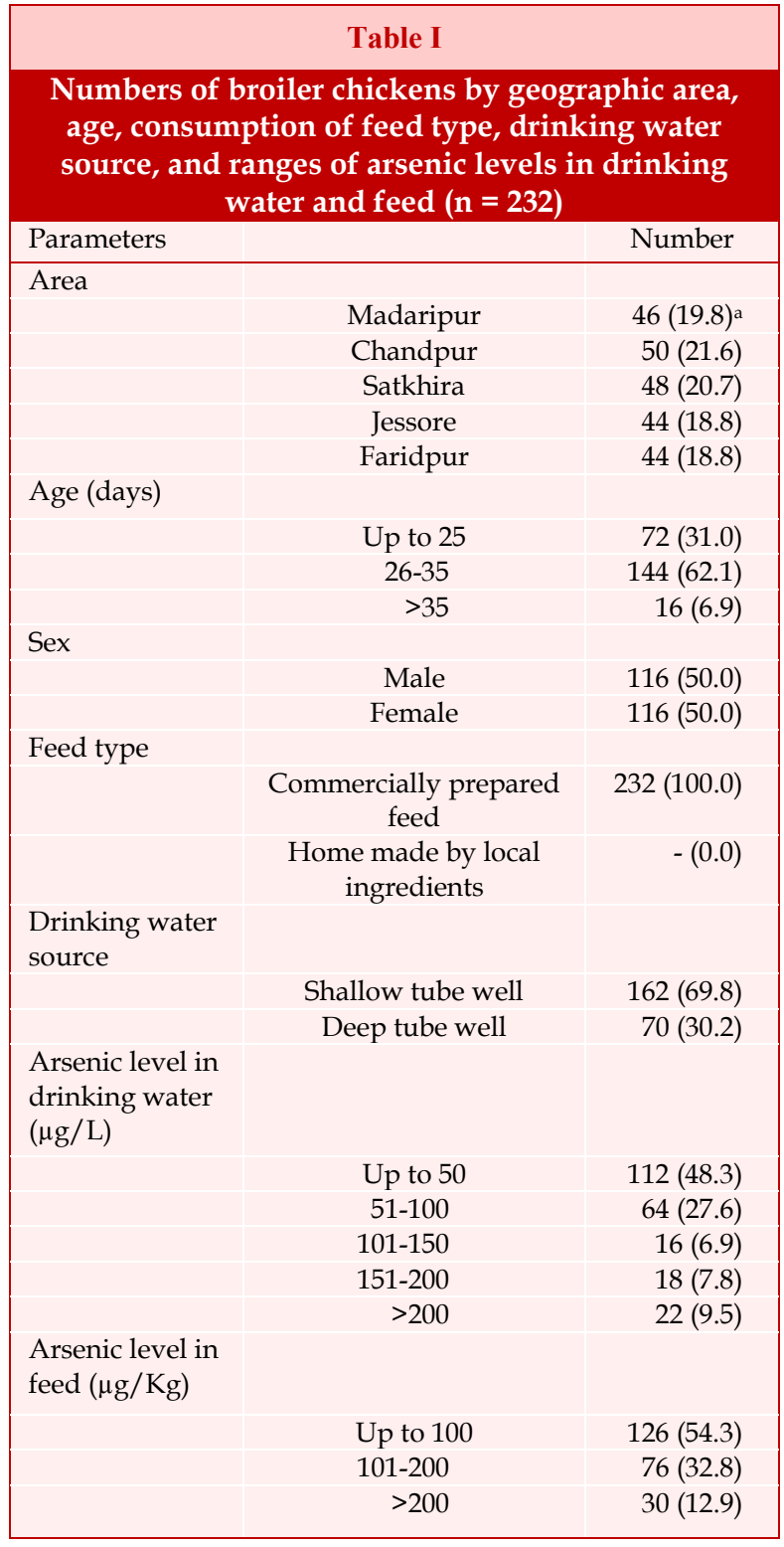

aNumber in parentheses shows percent of broiler chickens in each characteristic

\begin{tabular}{|l|c|c|c|}
\hline \multicolumn{4}{|c|}{ Table II } \\
\hline \multicolumn{4}{|c|}{ Tube well depth-wise arsenic concentration of } \\
water supplied to broiler chickens for drinking \\
purpose
\end{tabular}

Data are mean $\pm \mathrm{SE}$; cIndicates significant $(\mathrm{p}<0.01)$; $\dagger$ Any two means having different superscript letters differ significantly $(\mathrm{p}<0.05)$ 


\begin{tabular}{|c|c|c|c|c|}
\hline \multicolumn{5}{|c|}{ Table III } \\
\hline \multicolumn{5}{|c|}{ Area-wise concentrations of arsenic and its comparison in feed } \\
\hline Item & Area & Arsenic concentration $(\mu \mathrm{g} / \mathrm{kg})^{\dagger}$ & 95\% CI for Mean & F value \\
\hline \multirow[t]{6}{*}{ Feed } & Madaripur & $112.9 \pm 10.1^{\mathrm{b}}$ & $84.1-141.7$ & $6.62^{c}$ \\
\hline & Chandpur & $105.4 \pm 9.7 \mathrm{~b}$ & $92.5-118.4$ & \\
\hline & Satkhira & $106.0 \pm 9.9 \mathrm{~b}$ & $90.4-121.5$ & \\
\hline & Jessore & $107.2 \pm 10.4^{b}$ & $89.9-124.5$ & \\
\hline & Faridpur & $166.6 \pm 10.4^{a}$ & $142.4-190.8$ & \\
\hline & Overall & $119.0 \pm 4.7$ & $109.7-128.3$ & \\
\hline \multirow[t]{6}{*}{ Thigh muscle } & Madaripur & $68.6 \pm 11.5$ & 54.6-82.6 & 1.60 \\
\hline & Chandpur & $58.2 \pm 11.0$ & 47.4-69.1 & \\
\hline & Satkhira & $55.6 \pm 11.3$ & $39.8-71.3$ & \\
\hline & Jessore & $92.6 \pm 11.8$ & $46.1-139.0$ & \\
\hline & Faridpur & $66.3 \pm 11.8$ & $54.7-78.0$ & \\
\hline & Overall & $67.8 \pm 5.1$ & $57.7-77.9$ & \\
\hline \multirow[t]{6}{*}{ Liver } & Madaripur & $97.8 \pm 18.0$ & $77.3-118.3$ & 1.43 \\
\hline & Chandpur & $112.8 \pm 17.2$ & 70.9-154.7 & \\
\hline & Satkhira & $71.2 \pm 17.6$ & $57.8-84.6$ & \\
\hline & Jessore & $129.3 \pm 18.4$ & $67.0-191.5$ & \\
\hline & Faridpur & $101.3 \pm 18.4$ & $80.8-121.8$ & \\
\hline & Overall & $102.1 \pm 8.0$ & $86.3-118.0$ & \\
\hline \multirow[t]{6}{*}{ Kidney } & Madaripur & $89.5 \pm 16.7$ & 71.0-108.1 & 1.52 \\
\hline & Chandpur & $84.0 \pm 16.1$ & $61.1-107.0$ & \\
\hline & Satkhira & $65.3 \pm 16.4$ & $49.0-81.6$ & \\
\hline & Jessore & $122.1 \pm 17.1$ & 53.8-190.4 & \\
\hline & Faridpur & $82.3 \pm 17.1$ & 66.9-97.8 & \\
\hline & Overall & $88.2 \pm 7.5$ & 73.4-102.9 & \\
\hline \multirow[t]{6}{*}{ Lung } & Madaripur & $109.4 \pm 12.5$ & $86.1-132.6$ & 1.52 \\
\hline & Chandpur & $98.8 \pm 12.0$ & 73.6-124.1 & \\
\hline & Satkhira & $70.3 \pm 12.3$ & $58.5-82.1$ & \\
\hline & Jessore & $101.3 \pm 12.8$ & $61.3-141.3$ & \\
\hline & Faridpur & $102.9 \pm 12.8$ & $84.8-121.0$ & \\
\hline & Overall & $96.3 \pm 5.6$ & $85.2-107.3$ & \\
\hline \multirow[t]{6}{*}{ Skin } & Madaripur & $240.0 \pm 25.9$ & $185.5-294.6$ & 2.06 \\
\hline & Chandpur & $218.1 \pm 24.9$ & $177.6-258.6$ & \\
\hline & Satkhira & $158.1 \pm 25.4$ & $129.0-187.2$ & \\
\hline & Jessore & $253.8 \pm 26.5$ & $172.2-335.5$ & \\
\hline & Faridpur & $228.3 \pm 26.5$ & $183.4-273.3$ & \\
\hline & Overall & $218.8 \pm 11.7$ & $195.8-241.7$ & \\
\hline \multirow[t]{6}{*}{ Excreta } & Madaripur & $1417.4 \pm 131.0$ & $1053.7-1781.0$ & 1.01 \\
\hline & Chandpur & $1129.0 \pm 125.7$ & 936.3-1321.7 & \\
\hline & Satkhira & $1245.6 \pm 128.3$ & $1035.6-1455.7$ & \\
\hline & Jessore & $1075.2 \pm 134.0$ & 839.1-1311.4 & \\
\hline & Faridpur & $1243.3 \pm 134.0$ & 954.9-1531.7 & \\
\hline & Overall & $1221.8 \pm 58.3$ & $1106.8-1336.7$ & \\
\hline
\end{tabular}

Data are mean \pm SE; c Indicates significant $(\mathrm{p}<0.01)$; $†$ Any two means having different superscript letters differ significantly at $5 \%$ level of probability. Least significant difference (lsd) values are not quoted, as ten values are required to quote for the comparison of every arsenic exposure index

$8.0,88.2 \pm 7.5,96.3 \pm 5.6$ and $218.8 \pm 11.7$, respectively. Whereas, for excreta (dry weight) the figure was 1221.8 $\pm 58.3 \mu \mathrm{g} / \mathrm{kg}$. Arsenic contents in tissues and excreta of broiler chickens differed insignificantly $(p>0.05)$ at different areas.

Correlations of arsenic levels in thigh muscle, liver, kid- ney, skin, lung and excreta with that of drinking water as well as feed of broiler chickens presented a remarkable outcome. Results show that arsenic levels in broiler tissues and excreta significantly $(p<0.01)$ correlated with the arsenic concentration of well water (thigh muscle: $r=0.327$; liver: $r=0.326$; kidney: $r=0.316$; skin: $r=0.472$; lung: $r=0.457$; excreta: $r=0.851$ ). Similarly, 


\section{Table IV}

Multivariate multiple regression model for identifying the significant effects of the various arsenic exposure indexes on arsenic concentrations in tissues and excreta of broiler chickens $t$

\begin{tabular}{|c|c|c|c|c|c|c|c|}
\hline \multirow{2}{*}{$\begin{array}{l}\text { Regression indexes and explanatory } \\
\text { variables }\end{array}$} & \multicolumn{7}{|c|}{ Dependent Variables } \\
\hline & Thigh muscle & Liver & Kidney & Skin & Lung & Excreta & Excreta \\
\hline Intercept & 1.2 & 0.83 & -0.20 & -1.14 & 1.39 & -0.11 & -0.11 \\
\hline \multicolumn{8}{|l|}{ Regression coefficients } \\
\hline \multicolumn{8}{|l|}{ Area (Reference: Faridpur) } \\
\hline Madaripur & 0.1 & 0.1 & 0.2 & $0.2^{\mathrm{a}}$ & 0.2 & $0.3^{b}$ & $0.3^{b}$ \\
\hline Chandpur & -0.02 & 0.1 & 0.1 & 0.2 & 0.1 & $0.3^{b}$ & $0.3^{b}$ \\
\hline Satkhira & -0.2 & -0.2 & -0.1 & -0.2 & -0.2 & $0.3^{b}$ & $0.3^{b}$ \\
\hline Jessore & 0.1 & 0.2 & 0.1 & 0.1 & -0.04 & 0.1 & 0.1 \\
\hline Age (days) & $0.04^{\mathrm{b}}$ & $0.03^{\mathrm{b}}$ & 0.02 & $0.02^{\mathrm{a}}$ & 0.02 & -0.01 & -0.01 \\
\hline Sex & $0.2^{\mathrm{a}}$ & 0.1 & 0.1 & 0.02 & 0.1 & -0.01 & -0.01 \\
\hline Live weight (g) & -0.4 & -0.3 & -0.1 & 0.1 & -0.2 & $0.2^{\mathrm{a}}$ & $0.2^{\mathrm{a}}$ \\
\hline Arsenic in drinking water $(\mu \mathrm{g} / \mathrm{L})$ & $0.4^{\mathrm{b}}$ & $0.4^{\mathrm{b}}$ & $0.4^{\mathrm{b}}$ & $0.4^{\mathrm{b}}$ & $0.4^{\mathrm{b}}$ & $0.5^{\mathrm{b}}$ & $0.5^{\mathrm{b}}$ \\
\hline Arsenic in feed $(\mu \mathrm{g} / \mathrm{kg})$ & $0.5^{\mathrm{b}}$ & $0.6^{\mathrm{b}}$ & $0.6^{\mathrm{b}}$ & $0.7^{\mathrm{b}}$ & $0.6^{\mathrm{b}}$ & $0.7^{b}$ & $0.7^{b}$ \\
\hline $\mathrm{R}^{2}$ & 0.6 & 0.7 & 0.6 & 0.6 & 0.6 & 0.9 & 0.9 \\
\hline F value & $37.9^{\mathrm{b}}$ & $45.8^{\mathrm{b}}$ & $35.9^{\mathrm{b}}$ & $42.8^{\mathrm{b}}$ & $37.7 \mathrm{~b}$ & $135.5^{\mathrm{b}}$ & $135.52^{b}$ \\
\hline
\end{tabular}

andicates significant $(\mathrm{p}<0.05)$; b Indicates significant $(\mathrm{p}<0.01) ; \dagger$ Data on live weight and arsenic concentrations in drinking water, feed, thigh muscle, liver, kidney, skin, lung and excreta were used in the model after logarithmic transformation

significant positive correlations between arsenic contents in broiler tissues (except kidney) as well as excreta with arsenic content in feed were noticed (thigh muscle: $\mathrm{r}=0.165, \mathrm{p}<0.05$; liver: $\mathrm{r}=0.164$, $\mathrm{p}<0.05$; skin: $\mathrm{r}$ $=0.212, \mathrm{p}<0.01$; lung: $\mathrm{r}=0.199, \mathrm{p}<0.01$; excreta: $\mathrm{r}=$ $0.274, \mathrm{p}<0.01)$. Correlation study reveals a significant positive linear relationship between arsenic retained in thigh muscle, liver, kidney and skin with the age of the chickens (thigh muscle: $\mathrm{r}=0.176, \mathrm{p}<0.01$; liver: $\mathrm{r}=0.178$, $\mathrm{p}<0.01$; kidney: $\mathrm{r}=0.162, \mathrm{p}<0.05$; skin: $\mathrm{r}=0.255$, $\mathrm{p}<0.01)$. On the other hand, arsenic retained in lung and excreta were not significantly $(p>0.05)$ correlated with the age of broilers.

The multivariate multiple regression analysis provides the effect of area, age, sex, live weight and arsenic contents in drinking water and feed on the retention of arsenic in broiler tissues and its excretion through excreta. The significant $F$ values (and therefore $R^{2}$ values) of the model reveal the perfection of fitting the models to the data. On the basis of $\mathrm{R}^{2}$ values, it could be concluded that $61,65,59,63,60$ and $85 \%$ of the total variation of arsenic retention were in thigh muscle, liver, kidney, skin, lung and excreta, respectively, due to the variation of area, age, sex, live weight and arsenic contents in drinking water and feed (Table IV). For this analysis, Faridpur was considered as reference area. Other than skin, area exerted an insignificant $(p>0.05)$ effect on the arsenic retention in broiler tissues. In skin, geometric mean of arsenic was significantly $(\mathrm{p}<0.01)$ higher $[\{\exp (.239674)-1\} \times 100=27.08 \%]$ at Madaripur than that of Faridpur, when all other variables were set as constant. Likewise, compared to Faridpur, geometric mean of arsenic concentration in excreta was significantly $(\mathrm{p}<0.01)$ higher at Madaripur $(34.0 \%)$, Chandpur $(33.1 \%)$ and Satkhira $(30.0 \%)$. A significant positive linear relationship was observed between age and arsenic retention in body tissues, i.e., arsenic retention was boosted in most of the tissues with the advancement of age. With one day increase in age, geometric mean of arsenic increased by 3.6, 3.1 and 2.2\% in thigh muscle, liver and skin, respectively, when other factors remained constant. Sex exerted an insignificant $(p>0.05)$ effect on the arsenic excretion through excreta and its retention in various tissues, except thigh muscle. Geometric mean of arsenic retention was $16.1 \%$ higher in thigh muscle of male broiler chicken than that of 
female. Live weight of broiler chickens exhibited an insignificant effect on the arsenic retention in tissues, but showed a positive effect on arsenic escape through excreta. With $1 \%$ increment of live weight, arsenic excretion through excreta was increased by $0.2 \%$ (on an average). Significant $(\mathrm{p}<0.01)$ consistent enhancements of arsenic retention were in broiler tissues and excreta with the relative increment of arsenic levels in drinking water and feed. On an average $0.4,0.4,0.4,0.4,0.4$ and $0.5 \%$ arsenic residues were increased in thigh muscle, liver, kidney, skin, lung and excreta, respectively, for raising up $1 \%$ arsenic in drinking water, holding all other arsenic exposure indexes as constant. Conversely, $0.5,0.6,0.6,0.7,0.6$ and $0.7 \%$ increments of arsenic corresponded to thigh muscle, liver, kidney, skin, lung and excreta, respectively, for going up $1 \%$ arsenic in food, where other factors considered as constant.

\section{Discussion}

The results of this study show that wide ranges of arsenic present in drinking water, feed, tissues and excreta of broiler chickens at different locations of Bangladesh. Detected arsenic contents in drinking water were comparatively higher than allowable limit, but arsenic contents in broiler meat were within the admissible limit for human. The significant $\mathrm{R}^{2}$ values in multivariate multiple regression models fitted to the arsenic exposure data on tissues and excreta of broiler chickens indicate that arsenic contents in tissues and excreta were influenced by the arsenic contaminated feed and drinking water.

Drinking water and broiler feed were analysed for detection of possible sources of arsenic contamination to broiler chickens. Wide ranges of arsenic contamination in drinking water of broiler chickens could be associated with the different sources of contamination. In Bangladesh ground water arsenic concentrations are increasing day by day (Chakraborti et al., 2010) and with the progression of time uncontaminated wells and unaffected areas are being affected, which poses a greater risk of arsenic toxicity. Increasing extraction of ground water in Bangladesh might be a concern.

Arsenic concentration obtained in broiler feed was comparatively lower than the maximum acceptable concentration $(2,000 \mu \mathrm{g} / \mathrm{kg})$ in complete feedstuffs. Nowadays, poultry feed chiefly contain mixtures of plant-based products like maize and soybean cake. Those are mostly imported from countries, where background arsenic in ground water and soil may be comparatively lower than Bangladesh. Generally, levels of arsenic in soybean are very little (Wauchope, 1978) and arsenic uptake by maize from soil is very low (Duxbury et al., 2007), that may result in little arsenic in poultry feed.

Variable concentrations of arsenic were obtained in most organs of broilers. Presence of arsenic in broiler tissues is an indication of arsenic pollution in the environment of Bangladesh. Arsenic concentrations in animal tissues mainly depend on the dietary concentrations of arsenic, absorption rate and the homeostatic control mechanism of the body for arsenic (Doyle and Spaulding, 1978). In accordance with our study, variable concentrations of arsenic in chicken tissues under natural condition were reported by other investigators (Lasky et al., 2004; Mariam et al., 2004; Uluozlu et al., 2009). Conversely, Gacnik and Doganoc, (2000) did not find arsenic residue in meat, liver and kidney samples of poultry during 1994-1998 in Slovenia. Wallinga (2006) tested raw chicken from supermarkets of Minnesota and California, USA where he found $55 \%$ of the total 151 tested samples contained detectable levels of arsenic, ranging from 1.6 to $21.2 \mu \mathrm{g} /$ $\mathrm{kg}$. However, Wallinga (2006) found low or nondetectable levels of arsenic in certified organic and other "premium" brands, where the use of arseniccontaining feed additives were either legally prohibited or claimed not to have been used. Arsenic residue of skin> liver > lung> kidney> thigh muscle of broiler chicken is some extent similar as reported earlier (Lasky et al., 2004; Mariam et al., 2004). Highest arsenic residue obtained in broiler skin could not be compared due to lack of information. Arsenic has particular affinity to keratinized tissues (Huang et al., 1985) that might contribute in highest arsenic residue in skin. Chicken is a meat source of growing importance. It is reasonable to assume that arsenic take-up through chicken consumption has a significant influence on the arsenic burden to humans. However, arsenic levels in broiler meat did not violate the tolerance levels for human consumption $(2,000 \mu \mathrm{g} / \mathrm{kg}$ for liver and kidney; $500 \mu \mathrm{g} / \mathrm{kg}$ for muscle) set by the US FDA (FDA Regulations, 1992).

Presence of huge amounts of arsenic in excreta possibly due to simultaneous exposure of chickens to arsenic through feed and/or drinking water. Chiou et al. (1997) reported $879 \pm 45$ to $926 \pm 56 \mu \mathrm{g} / \mathrm{kg}$ arsenic in excreta of 32-week-old White Leghorn layers, whereas Anderson and Chamblee (2001) claimed to obtain $210 \pm 20$ to $580 \pm$ $110 \mu \mathrm{g} / \mathrm{kg}$ arsenic in excreta of 1 to 7 -weeks-old broilers in control study. Presence of relatively higher amount of arsenic in excreta in this investigation than the amounts reported previously (Chiou et al., 1997; Anderson and Chamblee, 2001) is possibly due to simultaneous exposure to arsenic through feed and/or drinking water. The inclusion of arsenic-rich feed and/ or drinking water resulted in the excretion of high arsenic in excreta (Morrison, 1969). However, much less attention has been given to the potential risks related to poultry waste. Use of arsenic-rich excreta and/or litter as fertilizers in agricultural fields elevating soil arsenic loads (Arai et al., 2003). Soil microbes convert arsenic to most toxic inorganic forms (Stolz et al., 2007) which seeping into nearest water tables and consequently 
pollutes the environment.

The significant elevation of arsenic in tissues and excreta resulted in the relative increment of arsenic in drinking water and/or feed. It is assume that arsenic contaminated drinking water and feed play a vital role in the elevation of arsenic in tissues as well as excreta. The strong positive correlation between the arsenic contents of drinking water and tissues as well as drinking water and excreta support these findings. However, drinking water arsenic is more detrimental to the living being than feed arsenic owing to its inorganic nature. With the advancement of age, concomitant increments of arsenic in most tissues were observed. This indicates the cumulative accumulation pattern of arsenic. Positive correlation between arsenic contents in tissues (thigh muscle, liver, kidney and skin) with age further justifies the findings.

To evaluate the real arsenic threat from food chain some of the researchers suggested determining the organic and inorganic ratio of arsenic in food items of animal origin. But the latest science is overturning conventional wisdom: some organic forms of arsenic created by the body's metabolism now appear to be more toxic than inorganic one (Styblo et al., 2002; Kligerman and Tennant, 2007). Nevertheless, organic and inorganic forms of arsenic may be converted to one another, in the body as well as in the environment (Stolz et al., 2007). So, determination of total arsenic (inorganic plus organic) in broiler tissues is robust enough to effectively predict the risk of arsenic toxicity from broiler products.

This result suggests that arsenic contaminated drinking water and feed play a vital role in the elevation of arsenic in broiler tissues as well as excreta. Although relatively small amounts of arsenic was obtained in tissues, but it must be taken into account due to its detrimental effects on consumers, especially there are multiple sources of simultaneous arsenic exposure. Even though the drinking water standard for arsenic has been reduced, the standard for arsenic residue in edible tissues has remained unchanged for decades that needs to be addressed.

\section{Acknowledgement}

The authors are thankful to United States Department of Agriculture (USDA) - Foreign Agricultural Service (FAS), USA for financial support of this project (Grant no. USDA/31/2006, BG-ARS-117).

\section{References}

Anderson BK, Chamblee TN. The effect of dietary 3-nitro-4hydroxyphenylarsonic acid (roxarsone) on the total arsenic level in broiler excreta and broiler litter. J Appl Poult Res. 2001; 10: 323-28.

Arai Y, Lanzirotti A, Sutton S, Davis JA, Sparks DL. Arsenic speciation and reactivity in poultry litter. Environ Sci Technol. 2003; 37: 4083-90.

Chakraborti D, Rahman MM, Das B, Murrill M, Dey S, Mukherjee SC, Dhar RK, Biswas BK, Chowdhury UK, Roy S, Sorif S, Selim M, Rahman M, Quamruzzaman Q. Status of groundwater arsenic contamination in Bangladesh: A 14year study report. Water Res. 2010; 44: 5789-02.

Chiou PWS, Chen KL, Yu B. Effects of roxarsone on performance, toxicity, tissue accumulation and residue of eggs and excreta in laying hens. J Sci Food Agric. 1997; 74: 229-36.

Clesceri LS, Arnold E, Greenberg R, Rhodes T. Standard methods for the examination of water and wastewater. 17th ed. Washington, DC, American Public Health Associaiton, 1989: 3010B.

Cox DH. Arsine evolution-electrothermal atomic absorption method for the determination of nanogram levels of total arsenic in urine and water. J Anal Toxicol. 1980; 4: 207-11.

Doyle JJ, Spaulding JE. Toxic and essential trace elements in meat: A review. J Anim Sci. 1978; 47: 398-19.

Duxbury JM, Panaullah G, Koo-Oshima S. Remediation of arsenic for agriculture sustainability, food security and health in Bangladesh, FAO, Rome, 2007, pp 1-28.

FDA Regulation. Code of Federal Regulations, 21 CFR 556.60. The Office of the Federal Register National Archives and Records. Food and Drug Administration, Washington, DC, 1992.

Gacnik KS, Doganoc DZ. Contamination of farm animals and fishes from Slovenia with heavy metals and sulfonamides. Bull Environ Contam Toxicol. 2000; 64: 235-41.

Hanaoka K, Goessler W, Ohno H, Irgolic KJ, Kaise T. Formation of toxic arsenical in roasted muscles of marine animals. Appl Organometal Chem. 2001; 15: 61-66.

Huang YZ, Qian XC, Wang GQ, Xiao BY, Ren DD, Feng ZY, Wu JY, Xu RJ, Zhang F. Endemic chronic arsenism in Xinjiang. Chin Med J. 1985; 98: 219-22.

Islam MS, Awal MA, Mostofa M, Begum F, Khair A, Myenuddin M. Effect of Spirulina on biochemical parameters and reduction of tissue arsenic concentration in arsenic induced toxicities in ducks. Int J Poult Sci. 2009; 8: 69 -74 .

Johnson RA, Wichern DW. Applied multivariate statistical analysis. 5th ed. New Delhi, PHI Learning Private Ltd., 2002, pp 383-95.

Khan SI, Ahmed AKM, Yunus M, Rahman M, Hore SK, Vahter M, Wahed MA. Arsenic and cadmium in food-chain in Bangladesh-an exploratory study. J Health Popul Nutr. 2010; 28: 578-84.

Kligerman AD, Tennant A. Insights into the carcinogenic mode of action of arsenic. Toxicol Appl Pharmacol. 2007; 222: 28188 . 
Lasky T, Sun W, Kadry A, Hoffman MK. Mean total arsenic concentrations in chicken 1989-2000 and estimated exposures for consumers of chicken. Environ Health Perspect. 2004; 112: $18-21$.

Mariam I, Iqbql S, Nagra SA. Distribution of some trace and macrominerals in beef, mutton and poultry. Int J Agri Biol. 2004; 6: 816-20.

Morrison JL. Distribution of arsenic from poultry litter in broiler chickens, soil, and crops. J Agric Food Chem. 1969; 17: 128890 .

Nachman KE, Graham JP, Price LB, Silbergeld EK. Arsenic: A roadblock to potential animal waste management solutions. Environ Health Perspect. 2005; 113: 1123-24.

Pandey PK, Yadav S, Nair S, Pandey M. Sampling and preservation artifacts in arsenic analysis: Implications for public health issues in developing countries. Current Science. 2004; 86: 1426-32.

Peters (ed). Recommended methods of manure analysis. Madison, WI: UW Ext Publication A3769 Cooperative Ext Publ Operations, 2003, pp 30-36.

Singh SK, Ghosh AK. Entry of arsenic into food material: A case study. World Appl Sci J. 2011; 13: 385-90.

Smith AH, Lingas EO, Rahman M. Contamination of drinking water by arsenic in Bangladesh: A public health emergency. Bull WHO. 2000; 78: 1093-103.

StataCorp. Stata statistical software: Release 10.0; Stata
Corporation: College Station, Texas, USA, 2007.

Steel RGD, Torrie JH. Principles and procedures of statistics: A biometrical approach. 2nd edn. New York: McGraw-Hill Book Company, 1980, pp 185-86.

Stolz JF, Perera E, Kilonzo B, Kail B, Crable B, Fisher E, Ranganathan M, Wormer L, Basu P. Biotransformation of 3nitro-4-hydroxybenzene arsenic acid (roxarsone) and release of inorganic arsenic by Clostridium species. Environ Sci Technol. 2007; 41: 818-23.

Styblo M, Drobna Z, Jaspers I, Lin S, Thomas DJ. The role of biomethylation in toxicity and carcinogenicity of arsenic: A research update. Environ Health Perspect. 2002; 110 (suppl. 5): 767-71S

Uluozlu OD, Tuzen M, Mendil D, Soylak M. Assessment of trace element contents of chicken products from turkey. J Hazard Mater. 2009; 163: 982-87.

Wallinga D. Playing chicken: Avoiding arsenic in your meat. The institute for agriculture and trade policy, food and health program, Minnesota 55404, USA, 2006.

Wauchope RD. Selenium and arsenic levels in soybeans from different production regions of the United States. J Agric Food Chem. 1978; 26: 226-28.

Zhao FJ, McGrath SP, Meharg AA. Arsenic as a food chain contaminant: Mechanisms of plant uptake and metabolism and mitigation strategies. Annu Rev Plant Biol. 2010; 61: 53559. 